\title{
REPRESENTASI WACANA GENDER DALAM UNGKAPAN BERBAHASA INDONESIA DAN BAHASA INGGRIS: ANALISIS WACANA KRITIS
}

\author{
Tri Rina Budiwati \\ Fakultas Sastra Jurusan Sastra Inggris Universitas Ahmad Dahlan \\ tri_rina_budiwati@uad.ac.id
}

\begin{abstract}
The result depicts that based on intra-linguistic analysis, English, and Indonesian idioms which contain gender discourse are in the forms of noun, phrases, Sub-clause, Simple sentence, Elliptical sentence, Compound, Complex, and Compound-Complex sentences. Based on the meaning and reference analysis, it is known that such idioms have various meanings: strength and weaknesses, success, marriage, sexuality, negative things, and wisdom. Besides, seen from the doer, the idioms can refer to men, women, and men and/or women. Based on Critical Discourse Analysis (CDA), such idioms can be analyzed based on the aspects of action, context, history, power, ideology and representation, which, then, are known that: (a) men are assumed as representative in various affairs and things (esp. in success and goodness); (b) men are active in marriage and sexuality; (c) women take more part in domestic domain; (d) women become negative metaphor; and (e) there is unequal relationship between women and men.
\end{abstract}

Keywords: Idioms, gender discourse, critical discourse analysis/CDA

\begin{abstract}
ABSTRAK
Hasil penelitian menunjukkan bahwa berdasarkan analisis secara intralinguistik, idiom dan ungkapan Bahasa Indonesia juga Bahasa Inggris yang mengandung wacana gender berbentuk Nomina, Frase nomina, Frase verba, Frase adjektiva, Frase preposisi, Anak kalimat, Kalimat Tunggal, Kalimat Tunggal (Elipsis), Kalimat Majemuk Setara, Majemuk Bertingkat dan Majemuk Campuran. Dari analisis makna dan acuan, diketahui adanya makna beragam: kelemahan dan kelebihan seseorang, kesuksesan, pernikahan, seksualitas, hal-hal negatif, dan kebijaksanaan. Dilihat dari pelakunya, idiom dan ungkapan tersebut mengacu kepada jenis kelamin laki-laki, perempuan dan laki-laki dan/atau perempuan. Berdasarkan analisis wacana kritis, terdapat aspek/karakteristik tindakan, historis, konteks, kekuasaan, ideologi dan representasi sehingga diketahui: (a) Laki-laki dianggap sebagai wakil banyak urusan (terutama urusan kesuksesan dan kebaikan); (b) Laki-laki sebagai pihak yang aktif dalam pernikahan dan seksualitas; (c) Perempuan lebih banyak berperan di ranah domestik; (d) Perempuan dijadikan perumpamaan hal-hal yang negatif; dan (e) Adanya hubungan yang tidak seimbang antara perempuan dan laki-laki.
\end{abstract}

Kata Kunci: Idiom dan ungkapan, wacana gender, analisis wacana kritis 


\section{PENGANTAR}

Kesadaran berbahasa (Language Awareness) merupakan sikap dan kemampuan yang mestinya dimiliki oleh para pengguna bahasa untuk ikut berperan aktif dan kritis dalam penggunaannya seharihari. Mengapa? Kenyataan menunjukkan bahwa bahasa telah sering digunakan untuk berbagai kepentingan, seperti menyampaikan informasi, pengetahuan, ideologi, bahkan untuk memanipulasi dan menyesatkan. Menyadari penggunaan bahasa, tidak hanya sadar akan fungsi bahasa, tetapi juga dapat membuat penggunanya (penutur dan pendengarnya) menggunakan bahasa itu dengan responsif, efektif, dan bertanggung jawab.

Salah satu bentuk kesadaran kritis berbahasa, tulisan ini berusaha mengkritisi penggunaan ungkapan (idiom dan peribahasa) dalam bahasa Indonesia dan bahasa Inggris yang merepresentasikan wacana gender. Idiom merupakan tingkatan satuan lingual yang sangat kompleks dan dalam serta pemahaman tentang idiom seringkali menunjukkan tingkat kemampuan seseorang dalam menguasai bahasa tertentu. Dengan demikian, idiom yang sangat dikuasai oleh penutur asli atau bukan asli merupakan representasi dari nilai-nilai budaya yang telah mewarnai ('mendarah daging') di dalam suatu bahasa. Salah satu wacana yang direpresentasikan dalam ungkapan/idiom, misalnya wacana gender merupakan hal yang menarik untuk dikaji dan dikritisi. Contoh idiom dalam bahasa Indonesia maupun bahasa Inggris.

(1) Di balik pria yang sukses, ada wanita di belakangnya.

(2) No woman, no cry

Dari 2 (dua) ungkapan di atas dipahami adanya wacana gender dan relasi gender yang mengungkapkan bahwa pria (lakilaki) tidak dapat berhasil tanpa dukungan perempuan (istri atau ibunya) dalam kalimat nomor satu. Kemudian kalimat nomor dua, jika tidak ada perempuan, tidak akan ada yang menangis karena laki-laki dianggap 'tabu' bila menangis. Ternyata wacana gender itu banyak ditemukan dalam ungkapan dan idiom.

Dalam hubungannya dengan representasi wacana tersebut, di dalam menganalisis wacana gender dalam ungkapan/idiom bahasa Indonesia dan bahasa Inggris didasarkan pada Analisis Wacana Kritis (Critical Discourse Analysis/ CDA). Tulisan ini bukanlah studi komparatif antara ungkapan Bahasa Indonesia dan Bahasa Inggris, tetapi merupakan deskripsi ungkapan bernuansa gender dalam kedua bahasa tersebut. Konteks di sini berarti bahasa itu dipakai untuk tujuan dan praktek tertentu (Eriyanto, 2001: 7). Dengan demikian, penggunaan frase dan kalimat pada ungkapan dan idiom yang berbahasa Indonesia dan Inggris tersebut akan dibedah secara intralinguistik (berdasarkan unsurunsur yang ada di dalam bahasa, misalnya makna idiom berdasar kamus), sekaligus kemudian dihubungkan dengan praktekpraktek sosial yang tengah berlangsung di dalam nilai-nilai masyarakat Indonesia (ekstralinguistik/unsur-unsur di luar bahasa).

Salah satu penambah khasanah dalam penelitian Linguistik (khususnya Analisis Wacana Kritis), penelitian ini penting untuk dilakukan. Pertama, penelitian ini merupakan salah satu kesadaran kritis dalam berbahasa untuk mewujudkan penggunaan bahasa yang responsif gender sebagai bagian dari tuntutan zaman. Kedua, penelitian ini merupakan salah satu kajian bahasa dan gender yang sering dilakukan oleh peneliti sebagai spesialisasi bidangnya untuk dapat mengungkapkan fenomena ini lebih dalam dan komprehensif.

Tujuan penelitian ini adalah (1) mendeskripsikan bentuk satuan lingual dalam ungkapan bahasa Indonesia dan Inggris yang merepresentasikan wacana gender; (2) mendeskripsikan makna dan acuan dalam ungkapan berbahasa Indonesia dan Inggris yang merepresentasikan wacana gender; dan (3) menganalisis wacana gender yang direpresentasikan dalam ungkapan 
bahasa Indonesia dan Inggris berdasarkan Analisis Wacana Kritis.

Kajian teoretis mengenai analisis wacana disertai contoh-contoh analisis teks media ditulis dengan lengkap dan runtut oleh Eriyanto (2001) dengan judul Analisis Wacana: Pengantar Analisis Teks Media. Buku ini membahas beberapa pendapat ahli wacana secara historis sejak zaman Roger Fowler, Van Leeuwen, Sara Mills sampai Fairclough dan mengupas contoh kasus dan penelitian mengenai analisis wacana teks di media. Penelitian yang berjudul Representing Bali and Balinese: "A Critical Discourse Analysis Approach to Bali's Hotel Brochures" bahwa upaya untuk menguak ideologi dan respresentasi yang dibangun dalam wacana turisme dan travel di Bali. Dalam tulisan ini ia berusaha menguak ideologi dan representasi yang terbangun dalam wacana turisme dan travel di Bali (Rianne Kartikasari Subijanto, 2004).

Tulisan mengenai Bias Gender dalam Bahasa Indonesia bahwa satuan lingual mulai dari bunyi, morfem, kata, frase, klausa, dan kalimat dalam bahasa Indonesia yang diasumsikan bias gender (Budiwati, 2003). Akan tetapi, secara khusus belum membahas ungkapan, idiom dan peribahasa yang mengandung wacana gender, terutama kajian Eriyanto, Subijanto, dan Budiwati akan menjadiacuan bagi peneliti, tentu saja, dengan objek studi yang berbeda. Pembahasan ini ditekankan pada deskripsi Analisis Wacana (secara intralinguistik) dan Analisis Wacana Kritis (secara ekstralinguistik) terhadap Idiom dan Ungkapan berbahasa Indonesia dan Inggris yang mengandung wacana gender.

\section{Ungkapan, Idiom, dan Peribahasa}

Ungkapan adalah aspek fonologis atau grafemis dari unsur bahasa yang mendukung makna, sedangkan idiom adalah (a) konstruksi dari unsur-unsur yang saling memilih, masing-masing anggota mempunyai makna yang ada hanya karena bersama yang lain, (b) konstruksi yang maknanya tidak sama dengan gabungan makna anggota-anggotanya, misalnya kambing hitam yang bermakna tidak sama dengan kambing maupun hitam (Kridalaksana, 1992: 62 dan 173). Selain itu, dalam World Book 2005 (Deluxe) idiom adalah a phrase or expression whose meaning cannot be understood from the ordinary meanings of the words in it. Jadi, ungkapan atau idiom dapat merepresentasikan makna atau wacana khusus yang terkandung di dalamnya. Termasuk dalam ungkapan adalah istilah peribahasa (provebs) yang bermakna "popular short saying, with words of advice or warning" (Oxford Advanced Learner's Dictionary of Current English, 672). Tambahan pula, salah satu definisi expression/ungkapan adalah "a putting into words or representing in language". Penggunaan Idiom sebagai berikut: (1) "the usual way in which the words of a particular language are joined together to express thought"; (2) "a phrase, construction, or expression that is recognized as a unit in the usage of a given language and either differs from the usual syntactic patterns or has a meaning that differs from the literal meaning of its parts taken together" (Webster, 480 dan 670).

\section{Wacana}

Wacana adalah satuan bahasa terlengkap dalam hierarki gramatikal merupakan satuan gramatikal tertinggi atau terbesar. Wacana ini direalisasikan dalam bentuk karangan yang utuh (novel, seri ensklopedia, dsb.), paragraf, kalimat atau kata yang membawa amanat yang lengkap. Definisi ini terkesan sempit karena bersifat linguistis (Kridalaksana, 1982: 179). Analisis wacana (discourse analysis) dengan analisis teks (text analysis) perbedaannya bahwa Analisis wacana memfokuskan pada struktur yang secara alamiah terdapat pada bahasa lisan, sebagaimana banyak terdapat dalam wacana seperti percakapan, wawancara, komentar, dan ucapan-ucapan. Sedangkan analisis teks memfokuskan pada struktur bahasa tulisan, sebagaimana terdapat pada 'teks' seperti esai, papan pengumuman, tanda-tanda lalu lintas, dan pada bab-bab (dalam buku) (Crystal, 1987: 116). 


\section{Analisis Wacana Kritis}

Salah satu cara yang paling produktif dalam memikirkan wacana bahwa wacana bukanlah sebagai sekolompok tanda atau bagian dari teks, tetapi sebagai 'praktek yang secara sistematis membentuk obyek yang dibicarakan (Foucalt dalam Mills, 1954: 17). Analisis wacana teks tertulis bertujuan mengeksplisitkan norma-norma dan aturanaturan yang implisit untuk memproduksi bahasa. Analisis wacana dapat dilihat sebagai reaksi terhadap bentuk linguistik yang lebih tradisional (linguistik formal dan struktural) (Mills, 1997: 135 dan 140). Tulisan ini lebih banyak mengacu pada pandangan Analisis Wacana Kritis (Critical Discourse Analysis/ $C D A$ ). Analisis wacana dalam paradigma ini menekankan pada konstelasi kekuatan yang terjadi pada proses produksi dan reproduksi makna. Individu tidak dianggap sebagai subyek netral yang dapat menafsirkan secara bebas sesuai dengan pikirannya karena sangat berhubungan dan dipengaruhi oleh kekuatan sosial yang ada dalam masyarakat.

Bahasa di sini tidak dipahami sebagai medium yang netral yang terletak diri $\mathrm{Si}$ pembicara. Bahasa dalam pandangan wacana kritis dipahami sebagai representasi yang berperan dalam membentuk subyek tertentu, tema-tema wacana tertentu, maupun strategi-strategi di dalamnya. Oleh karena itu, analisis wacana kritis dipakai untuk membongkar kuasa yang ada di dalam setiap proses bahasa: batasan-batasan apa yang diperkenankan menjadi wacana, perspektif yang mesti dipakai, topik apa yang dibicarakan. Berikut ini diungkapkan karakteristik penting dari analisis wacana kritis sebagai berikut: Pertama, Tindakan merupakan wacana yang dipahami sebagai sebuah tindakan (action). Seseorang yang berbicara atau menulis bukan ditafsirkan bahwa dia menulis atau berbicara untuk dirinya sendiri, tetapi untuk berinteraksi dan berhubungan dengan orang lain. Wacana dipandang sebagai sesuatu yang bertujuan, misalnya untuk mempengaruhi, mendebat, membujuk, dsb. Selain itu, wacana dipahami sebagai sesuatu yang diekspresikan secara sadar, terkontrol, bukan sesuatu yang di luar kendali atau diekspresikan di luar kesadaran. Kedua, Konteks merupakan analisis wacana kritis mempertimbangkan konteks dari wacana, seperti latar, situasi, peristiwa, dan kondisi. Wacana di sini dipandang diproduksi, dimengerti, dan dianalisis pada suatu konteks tertentu. Analisis wacana juga memeriksa konteks dari komunikasi: siapa yang mengkomunikasikan dengan siapa dan mengapa; dalam jenis khalayak dan situasi apa; melalui medium apa; bagaimana perbedaan tipe dari perkembangan komunikasi; dan hubungan untuk setiap masing-masing pihak. Ada beberapa konteks yang penting karena berpengaruh terhadap produksi wacana. (1) partisipan wacana, latar siapa yang memproduksi wacana. Jenis kelamin, umur, pendidikan, kelas sosial, etnis, agama, dalam banyak hal relevan dalam menggambarkan wacana. (2) setting sosial tertentu, seperti tempat, waktu, posisi pembicara dan pendengar atau lingkungan fisik adalah konteks yang berguna untuk mengerti suatu wacana.

Ketiga, Historis merupakan Salah satu aspek penting untuk bisa mengerti teks adalah dengan menempatkan wacana itu dalam konteks historis tertentu. Oleh karena itu, pada waktu melakukan analisis perlu tinjauan untuk mengerti mengapa wacana yang berkembang atau dikembangkan seperti itu, mengapa bahasa yang dipakai seperti itu, dsb. Keempat, Kekuasaan bahwa konsep kekuasaan adalah salah satu kunci hubungan antara wacana dengan masyarakat. Seperti kekuasaan lakilaki dalam wacana menganalisis seksisme, kekuasaan berbentuk dominasi pengusaha kelas atas kepada bawahan, dsb. Analisis wacana kritis tidak membatasi dirinya pada detil teks atau struktur wacana saja, tetapi juga menghubungkan dengan kekuatan dan kondisi sosial, politik, ekonomi, dan budaya tertentu. Aspek kekuasaan penting dikritisi untuk melihat apa yang disebut kontrol. Sering kelompok dominan lebih mempunyai akses seperti pengetahuan, uang dan pendidikan dibandingkan dengan kelompok tidak dominan. 
Kelima, Ideologi merupakan konsep yang sentral dalam analisis wacana kritis karena teks, percakapan, dan lain-lain adalah bentuk dari praktek ideologi atau pencerminan dari ideologi tertentu. Teori klasik mengatakan bahwa ideologi dibangun oleh kelompok dominan dengan tujuan untuk mereproduksi dan melegitimasi dominasi mereka. Ideologi membuat anggota dari suatu kelompok akan bertindak dalam situasi yang sama, dapat menghubungkan masalah mereka, dan memberikan kontribusi dalam membentuk solidaritas dan kohesi dalam kelompok. Ideologi memiliki beberapa implikasi penting. (1) ideologi secara inheren bersifat sosial, tidak personal, atau individual: ia membutuhkan share di antara anggota kelompok dengan orang lain. (2) meskipun bersifat sosial, ideologi digunakan secara internal di antara anggota kelompok. Oleh karena itu, analisis wacana tidak bisa menempatkan bahasa secara tertutup, tetapi harus melihat konteks terutama bagaimana ideologi dari kelompok-kelompok yang ada tersebut berperan dalam membentuk wacana.

Keenam, Representasi adalah produksi makna atau konsep yang kita pahami melalui bahasa, kode, dan gambar. Representasi menghubungkan konsep dan bahasa yang membuat kita mengacu pada objek, peristiwa atau orang di dunia nyata. Representasi bisa dimaknai mendeskripsikan gambaran atau imajinasi dalam pikiran kita atau merepresentasikan hal lain. Dalam hal ini bahasa merupakan sistem representasi. Ia berfungsi sebagai tanda yang merepresentasikan konsep atau ide kita (Eriyanto, 2001: 6-14).

Penelitian linguistik dilakukan model penelitian kualitatif yang di dalamnya memuat sifat deskriptif dengan tujuan utama menemukan pola-pola pembentukan, kaidah-kaidah yang bersifat mengatur di dalam bahasa itu, menemukan sistem fonem, morfem, kata, frase, kalimat, wacana dan semantik, serta menemukan satuan-satuan lingual beserta identitasnya. Penelitian bahasa juga sangat mementingkan masalah konteks, baik konteks bahasa maupun situasi. Konteks penggunaan bahasa dalam wacana, analisis wacana kritis juga dapat dikategorikan ke dalam penelitian kualitatif yang bersifat deskriptif dan argumentatif (Subroto, 1991: 5). Triangulasi sumber (data) dan metode serta teknik. Triangulasi data dapat diperoleh dari sumber data primer yang diambil dari beberapa kamus ungkapan dan idiom serta sumber lain, kemudian dikonfirmasikan dengan sumber data sekunder berupa pengetahuan dan pemahaman peneliti sebagai penutur asli bahasa Indonesia dan pembelajar bahasa Inggris selama kurang lebih 23 tahun dan pengajar selama 10 tahun.

Data primer dalam penelitian ini adalah berupa ungkapan, idiom dan peribahasa berbahasa Indonesia dan Inggris. Data sekunder penelitian ini berupa pengetahuan dan pemahaman peneliti tentang bahasa Inggris dan Indonesia serta teori-teori analisis wacana dan gender dari berbagai sumber.

Pengumpulan data penelitian ini menggunakan metode simak dengan teknik dasar berupa teknik sadap dan teknik lanjutannya yaitu teknik catat. Metode simak ialah metode yang dilakukan dengan menyimak penggunaan bahasa; teknik sadap ialah teknik menyadap pembicaraan atau menyadap penggunaan bahasa yang dilakukan oleh peneliti dengan segenap kecerdikan dan kemauannya; teknik catat ialah teknik pencatatan data pada kartu data yang segera dilanjutkan dengan klasifikasi Sudaryanto (1988: 2-9). Teknik sadap ini berhubungan dengan metode instrospeksi (instrospection method) untuk menganalisis nilai dan perilaku dan apa pun yang ada dalam komunitas atau masyarakatnya sendiri (Fasold, 1990: 47-50).

Analisis berdasarkan karakteristik analisis wacana kritis seperti tindakan, konteks, historis, kekuasaan, dan ideologi (van Dijk, Fairclough, dan Wodak via Eriyanto, 2001: 6-14).

\section{PEMBAHASAN}

Ungkapan yang menjadi fokus penelitian ini adalah idiom dan peribahasa 
dalam bahasa Indonesia dan Inggris yang berjumlah 245 ( 31 berbahasa Indonesia dan 214 berbahasa Inggris) dan tidak semua dianalisis dalam bab ini.

\section{Satuan Lingual Ungkapan Berbahasa Indonesia dan Inggris yang Merepresentasikan Wacana Gender}

Dari hasil klasifikasi data, didapatkan beberapa bentuk satuan lingual yakni Nomina (2), Frase Nomina (147), Frase Verba (10), Frase Ajektiva (1), Frase Preposisi (4), sub klausa (1), Kalimat Tunggal (27), Kalimat Tunggal/Subjek dihilangkan/Elliptical sentence (17), Kalimat Majemuk Setara (11), Kalimat Majemuk Bertingkat (21) dan Kalimat Majemuk Campuran (4). Berdasarkan data dapat diketahui bahwa idiom dan peribahasa yang merepresentasikan wacana gender dalam Bahasa Indonesia kebanyakan berbentuk Kalimat Majemuk Bertingkat (15). Selain itu, juga ada yang berbentuk Frase Nomina (1), Frase Verba (1), Frase ajektiva (1), Kalimat Tunggal/Sederhana (3), Kalimat Majemuk Setara (6), dan Kalimat Majemuk Campuran (4).

\section{Idiom dan Peribahasa Gender dalam Frase Nomina}

Frase nomina (kata benda) gender dalam Bahasa Indonesia dapat dilihat dalam data (193) berikut ini.

\section{(193) Anak Adam}

Kata anak merupakan kata benda yang menjadi inti frase dan dijelaskan dengan nomina lain Adam. Dalam frase tersebut unsur anak tidak dapat dihilangkan atau diganti unsur lain karena jika diganti dengan putra menjadi Putra Adam, misalnya, maknanya menjadi lain. Frase Putra Adam berarti anak laki-laki Nabi Adam, manusia pertama di dunia. Sedangkan frase anak Adam bermakna manusia secara umum (karena semua manusia ini adalah keturunan Adam).

\section{Idiom dan Peribahasa Gender dalam Frase Verba}

Frase verba gender dalam Bahasa Indonesia dapat dilihat pada data (199) berikut ini.
(199) dimabuk bayang-bayang

Pada frase verba di atas, kata dimabuk merupakan verba inti yang mendapat penjelas bayang-bayang. Verba dimabuk atau lengkapnya dibuat mabuk akan merupakan unsur inti yang tidak dapat dihilangkan karena akan mengubah makna frase tersebut. Frase dimabuk bayang-bayang bermakna gila akan sesuatu.

\section{Idiom dan Peribahasa Gender dalam Frase Adjektiva}

Frase ajektiva gender dalam Bahasa Indonesia dapat dilihat dalam data (220) berikut ini.

(220) Jinak-jinak merpati

Frase pada data (220) tersebut mengandung unsur/kata sifat jinak yang diulang dan dijelaskan dengan kata merpati. Ajektiva jinak-jinak merupakan unsur inti yang diterangkan oleh kata benda merpati yang mengandung makna jinak seperti merpati (seolah menurut tetapi jika didekati menjauh).

\section{Idiom dan Peribahasa Gender dalam Kalimat Tunggal}

Kalimat Tunggal yang bernuansa gender dalam Bahasa Indonesia terdapat pada data (196), (204), dan (209) berikut ini.

(196) Bandot tua makan lalap muda

(204) Upah bidanpun tiada dibayar

(209) Perkawinan tempat mencahari

Dalam data (196) terdapat 1 (satu) pokok pikiran atau hal yang dibicarakan yakni adanya 1 (satu) pelaku (Bandot tua), 1 (satu) verba/tindakan (makan) dan objek/yang terkena tindakan (lalap muda). Sementara itu, data (204) merupakan kalimat yang mengandung 1 (satu) hal yang dibicarakan yakni tentang 1 (satu) subjek/pelaku (Upah bidan), 1 (satu) verba/tindakan berupa tiada dibayar. Sedangkan dalam data (209) terdapat 1 (satu) subjek yakni perkawinan sebagai pokok pembicaraan dan pelengkap berupa tempat mencahari. 


\section{Idiom dan Peribahasa Gender dalam Kalimat Majemuk Setara}

Kalimat majemuk setara terdapat pada data (195), dan (202), berikut ini.

(195) Belum beranak berbesan dahulu

(202) Beranak tiada berbidan

Data (195) merupakan kalimat majemuk setara karena memiliki 2 (dua) klausa independen/utama, yang masing-masing dapat berdiri sendiri sebagai kalimat, yakni belum beranak dan berbesan dahulu. Di antara dua klausa itu sebenarnya terdapat kata penghubung tetapi sehingga kalimatnya menjadi:

(195a) Belum beranak, tetapi berbesan dahulu

Begitu pula data (202) yang juga terdiri dari 2 (dua) klausa utama, yang masingmasing dapat berdiri sendiri, yakni beranak dan tiada berbidan, yang sebenarnya juga dihubungkan dengan kata tetapi, tetapi tidak diperlihatkan, sehingga kalimatnya menjadi:

(202a) Beranak, tetapi tiada berbidan

Kebetulan data yang berbentuk kalimat majemuk setara dari yang terkumpul tidak memiliki kata penghubung yang ditampakkan, tetapi diganti dengan tanda koma (,) karena itu menjadi ciri khas peribahasa dalam Bahasa Indonesia.

\section{Idiom dan Peribahasa Gender dalam Kalimat Majemuk Bertingkat}

Kalimat majemuk bertingkat terdapat dalam data 16 data. Berikut ini akan dipaparkan analisisnya beberapa dari data tersebut.

(197) Bapak burik anaknya tentu rintik

(198) Kalu bapaknya bergendang, masa anaknya tak kan menari

(205) Orang bini-binian, beranak tak boleh disuruh

Data (197) tersebut merupakan kalimat majemuk bertingkat karena kalimat itu terdiri dari 1 (satu) induk kalimat (anaknya tentu rintik) dan 1 (satu) anak kalimat (bapaknya burik). Induk kalimat tersebut dapat berdiri sendiri sebagai kalimat, sedangkan anak kalimat tidak dapat berdiri sendiri. Dalam data tersebut, sepertinya anak kalimat (bapaknya burik) dapat berdiri sendiri, tetapi jika digabungkan dengan induk kalimat (anaknya tentu rintik) sebab kalimat tersebut sebenarnya mengandung kata penghubung jika, sehingga jika dieksplisitkan akan menjadi:

(197a) Jika bapaknya burik, anaknya tentu rintik

Data (198) merupakan kalimat majemuk bertingkat dengan 1 (satu) induk kalimat (masa anaknya tak kan menari) dan anak kalimat (kalau bapaknya bergendang) dengan kata gabung yang dieksplisitkan kalau. Kata penghubung tersebut menjadikan anak kalimat itu tidak dapat berdiri sendiri sebagai kalimat.

Sementara itu, kata penghubung jika atau kalau dan maka tidak ditampakkan pada data (205). Data tersebut memiliki 1 (satu) anak kalimat (Orang bini-binian) dan 1 (satu) induk kalimat (beranak tak boleh disuruh). Jika dieksplisitkan kata penghubungnya, maka akan menjadi seperti berikut:

(205a) Kalau orang bini-binian, maka beranak tak boleh disuruh

\section{Idiom dan Peribahasa Gender dalam Kalimat Majemuk Campuran}

Data yang dapat dikategorikan ke dalam kalimat majemuk campuran adalah data (194), dan (206) berikut ini.

(194) Lain yang memperanakan, lain yang dipanggil bapa celaka

(206) Hilang bini, hilang budi badan

Data (194) dapat dikategorikan sebagai kalimat majemuk campuran dengan dasar bahwa kalimat tersebut terdiri dari 2 (dua) induk kalimat (lain yang disebutkan 2 kali) dan 2 (dua) anak kalimat (yang memperanakan dan yang dipanggil bapa). Meskipun induk kalimat berbentuk kata (lain), tetapi maksudnya adalah yang ini lain dari yang itu. Dua induk kalimat itu mestinya digabung dengan kata penghubung dan, sehingga menjadi:

(194a) Lain yang memperanakan dan lain yang dipanggil bapa

Sedangkan anak kalimat pada induk kalimat yang pertama (yang memperanakan) 
merupakan pelengkap dari kalimat Orang inilah yang memperanakan dan anak kalimat pada induk kalimat yang kedua (yang dipanggil bapa) merupakan pelengkap dari kalimat Orang inilah yang dipanggil bapa. Data (194) merupakan kalimat yang sangat kompleks karena adanya pelesapan (peristiwa elipsis) subjek/pelaku pada anak kalimat dan pelesapan tindakan pada induk kalimat.

Data (206) juga merupakan kalimat majemuk campuran dengan pelesapan pada kata hubung, sehingga jika akan dianalisis, perlu diberi atau ditampakkan kata penghubungnya dahulu menjadi:

(206a) ذika hilang bini dan hilang budi, maka badan celaka

Dengan demikian, maka jelas bahwa data tersebut terdiri dari 2 (dua) anak kalimat (jika hilang bini dan jika hilang budi) dan 1 (satu) induk kalimat (badan celaka).

\section{Bentuk Satuan Lingual Idiom dan Peribahasa Gender dalam Bahasa Inggris}

Berdasarkan data dapat diketahui bahwa kebanyakan idiom dan peribahasa dalam Bahasa Inggris yang merepresentasikan wacana gender berbentuk Frase Nomina (146). Kemudian setelah itu berturutturut jumlahnya terdapat bentuk Kalimat tunggal (24), Kalimat tunggal (dengan subjek dihilangkan/Elliptical sentence) (17), Frase Verba (9), Kalimat Majemuk Setara (5), Kalimat Majemuk Bertingkat (6), Frase Preposisi (4), Nomina/Noun (2) dan Anak Kalimat (1).

Berikut ini dipaparkan analisis setiap bentuknya pada data-data yang representatif.

\section{Idiom dan Peribahasa Gender dalam Nomina/Noun}

Sebenarnya banyak idiom yang mengandung wacana gender yang berbentuk nomina/kata benda, tetapi data yang diambil dan dianalisis hanya 2 (dua).
(132) Bimboy
(140) Beddyboy

Sebenarnya kalau dilihat sekilas dua data tersebut berbentuk frase nomina, tetapi 2 (dua) idiom itu telah menjadi kata benda.

\section{Idiom dan Peribahasa Gender dalam Frase Nomina/Noun Phrase}

Sebagaimana telah dijelaskan sebelumnya bahwa frase nomina merupakan kelompok kata yang memiliki unsur inti kata benda. Setelah diklasifikasi, sebagian besar data yang terkumpul berbentuk frase nomina. Berikut ini analisis beberapa data yang representatif.

(04) A made man

(18) All the world and his wife

(113) The weaker sex

Data (04) merupakan frase nomina dengan kata man sebagai unsur inti dan article $a$ dan past participle made sebagai penjelas yang terletak di depan unsur inti (pre-modifier). Frase nomina pada data (18) juga memiliki unsur inti kata benda (world) dan unsur penjelas di depan (all the..) dan di belakang unsur inti (and his wife).Unsur penjelas yang terletak di belakang ini seolah kedudukannya setara dengan unsur inti dengan adanya kata penghubung and, tetapi unsur yang paling inti dalam frase itu sebenarnya adalah kata benda world.

Frase nomina The weaker sex pada data (113) memiliki unsur inti nomina sex dan unsur penjelas di depannya (the weaker). Unsur penjelas itu terdiri dari artikel atau penunjuk the dan ajektiva/kata sifat yang mengandung tingkat perbandingan (....er yang berarti lebih...; weaker berarti lebih lemah).

\section{Idiom dan Peribahasa Gender dalam Frase Verba/Verb Phrase}

Frase verba adalah frase yang memiliki unsur inti berupa verba. Idiom yang merepresentasikan wacana gender dalam Bahasa Inggris banyak yang berbentuk frase verba, tetapi dalam sub bagian ini hanya akan dijelaskan data yang representatif.

(109) take as wife

(154) give away 
Data (109) merupakan frase verba dengan unsur inti take dan penjelas as wife di belakang unsur inti (post-modifier) yang akan membentuk satu kesatuan makna. Frase verba pada data (154) memiliki unsur inti verba give yang harus ada dan unsur penjelas di belakangnya (away). Bentuk semacam ini biasanya juga disebut phrasal verb (verba yang berbentuk frase dalam Bahasa Indonesia).

\section{Idiom dan Peribahasa Gender dalam Frase Preposisi}

Dari data yang terkumpul terdapat 4 (empat) frase preposisi yang berwacana gender dalam Bahasa Inggris.

(68) For his own good

(84) In the family way

(115) To a man

Frase preposisi pada data (68), (84) dan (115) yang masing-masing memiliki unsur inti kata depan for, in dan to yang diikuti dengan unsur penjelas berbentuk frase nomina (his own good, the family way dan a man).

\section{Idiom dan Peribahasa Gender dalam Anak Kalimat/Sub -Clause}

Dari data yang terkumpul terdapat 1 (satu) anak kalimat/sub-clause yang merepresentasikan wacana gender.

(27) Before one can say jack robinson

Anak kalimat pada data (27) tersebut terdiri dari kata penghubung before (sebelum), subjek/pelaku (one), verba/tindakan (can say), dan objek/yang dikenai tindakan (jack robinson).

\section{Idiom dan Peribahasa Gender dalam Kalimat Tunggal/Sederhana}

Kalimat Tunggal yang bernuansa gender dalam Bahasa Inggris dapat dilihat pada 24 data, tetapi hanya beberapa yang akan dipaparkan dalam analisis, misalnya data (58), (241), dan (243) berikut ini.

(58) Every man has his price

(241) One tongue is enough for a woman

(243) The way to a man's heart is through

his stomach
Kalimat tunggal pada data (58) masingmasing memiliki 1 (satu) subjek/pokok pembicaraan/pelaku (Boys dan Every man) dengan 1 (satu) verba/tindakan (will be dan has). Sementara itu, kalimat tunggal pada data (241) dan (243) masing-masing terdiri dari 1 (satu) pokok pembicaraan/subjek (One tongue, dan The way...) dan 1 (satu) verba/ tindakan yang sama (is) karena setelah verba is adalah penjelas/complement.

\section{Idiom dan Peribahasa Gender dalam Kalimat Tunggal (Subjek yang dihilangkan/Elliptical \\ Sentence )}

Berbeda dengan kalimat tunggal sebelum-nya yang dieksplisitkan subjek/ pokok pem-bicaraannya, pada sub-bagian ini subjeknya dihilangkan/ mengalami pelesapan/elipsis. Hal demikian terdapat pada 17 data dan analisisnya dipaparkan pada beberapa data saja.

(54) Eat at man's salt

(67) Fight to the last man

(95) Lead a woman to the altar

Semua kalimat tunggal/simple sentence pada data tersebut di atas sebenarnya memiliki subjek/pelaku yang dihilangkan/ disembunyikan dengan alasan misalnya sudah jelas siapa pelakunya atau bahkan tidak penting atau siapapun ia dapat menjadi pelakunya. Dengan demikian nomina/ subjek 'seseorang'/ia dapat menjadi pelaku yang melakukan tindakan (eat, fight, dan lead) pada kalimat-kalimat tersebut.

\section{Idiom dan Peribahasa Gender dalam Kalimat Majemuk Setara/ Compound Sentence}

Kalimat Majemuk Setara yang merepresentasikan wacana gender dalam Bahasa Inggris dapat dilihat pada data berikut ini.

(188) Man proposes God disposes

(229) Cowards die many times, but a brave man only dies once

Kalimat Majemuk Setara/Compound sentence pada data (188) terdiri dari 2 (dua) induk kalimat/klausa independen 
(Man proposes dan God disposes) dan kata penghubung dan yang dimplisitkan, sehingga menjadi:

(188a) Man proposes and God disposes

Kedua induk kalimat tersebut jika dipisahkan dapat berdiri sendiri sebagai kalimat.

Begitu pula data (229) yang juga berbentuk kalimat majemuk setara yang terdiri dari 2 (dua) induk kalimat (Cowards die many times dan a brave man only dies once) yang dihubungkan dengan kata penghubung but.

\section{Idiom dan Peribahasa Gender dalam Kalimat Majemuk Bertingkat}

Kalimat Majemuk Bertingkat/Complex sentence dalam Bahasa Inggris yang merepresentasikan wacana gender dapat dilihat pada data-data berikut ini.

(85) Jack is good as his master

(236) If you wish good advice, consult an old man

Kalimat majemuk bertingkat pada data (85) terdiri dari induk kalimat (Jack is good) dan anak kalimat (as his master is) dengan kata penghubung as pada anak kalimatnya. Kalimat majemuk bertingkat pada data (236) yang terdiri dari anak kalimat (If you wish good advice) dan induk kalimat (consult an old man) dengan kata penghubung if pada anak kalimatnya. Pada induk kalimatnya, subjek (you) dilesapkan.

\section{Makna dan Acuan dalam Ungkapan Berbahasa Indonesia dan Inggris yang Merepresentasikan Wacana Gender}

Berdasarkan makna ungkapan (idiom dan peribahasa) tercantum di dalam beberapa kamus yang telah diteliti dan melihat konteks situasional dan sosial budaya, maka berikut ini dipaparkan acuan yang tersirat di dalam idiom dan peribahasa.

Fokus penelitian ini adalah wacana gender, maka peneliti berusaha menghubungkan kata-kata yang digunakan dalam idiom dan peribahasa dengan acuan gender yang tersirat dalam idiom dan peribahasa tersebut. Misalnya, meskipun dalam idiom a made man terdapat kata man yang bermakna laki-laki, tetapi setelah dipahami, idiom tersebut tidak hanya mengacu pada laki-laki, tetapi juga perempuan atau keduajenis kelamin. Analisis seperti inilah (berdasarkan aspek leksikal, konteks situasional dan sosial budaya) yang dilakukan peneliti dalam menangkap acuan gender pelakunya.

Dengan hanya melihat sekilas pada data tidak berarti dapat diketahui bahwa ada keseimbangan acuan gender pada lakilaki dan perempuan. Hal ini disebabkan oleh istilah-istilah yang mengandung makna laki-laki sering digunakan untuk mengacu pada kedua jenis kelamin. Misalnya kata man atau pronomina he, his yang sering digunakan untuk mengacu pada pelaku laki-laki dan perempuan. Begitu juga katakata yang sebenarnya bermakna perempuan (misalnya mother, bagai gadis belum berlaki, dan lain-lain) yang digunakan untuk mengacu kepada kedua jenis kelamin yang memiliki sifat negatif yang diumpamakan seperti perempuan. Misalnya, peribahasa Bagai anak dara sudah berlaki bermakna anak perawan yang tiada bermalu lagi pemalas serta pengotor dan panjang mata. Jelas ini merupakan perumpamaan yang melecehkan salah satu jenis kelamin, yaitu perempuan.

Ide kesuksesan dan kebaikan serta keunggulan diperupamakan dengan istilah yang bermakna laki-laki, tetapi digunakan untuk mengacu pada kedua jenis kelamin (kesuksesan secara umum). Misalnya, idiom a man of high principles, a man of mark, a man of means, a man of note, a man of substance yang bermakna positif, kesuksesan, dan kekayaan. Tentu hal demikian ini dapat dikatakan sebagai ketidakseimbangan perlakuan jenis kelamin dalam bahasa.

Selain itu, ada pula peribahasa seperti Bandot tua makan lalap muda yang jika dilihat pelakunya memang laki-laki, tetapi yang menjadi korban (pelecehan) adalah perempuan (gadis). Peribahasa ini bermakna laki-laki tua yang berbini gadis. 


\section{Representasi Wacana Gender dalam Ungkapan Berbahasa Indonesia dan Inggris berdasarkan Analisis Wacana Kritis}

Selanjutnya, ungkapan (idiom dan peribahasa) dalam Bahasa Indonesia dan Inggris tersebut dianalisis berdasarkan tindakan, konteks, historis, kekuasaan, ideologi. dan representasi.

\section{Tindakan}

Wacana gender yang direpresentasikan dalam idiom dan peribahasa tersebut sudah mendarah daging dan merefleksikan pikiran dan pendapat masyarakat tentang hubungan laki-lakidan perempuan. Berdasarkananalisis terhadap idiom dan peribahasa tersebut nampak jelas bahwa tindakan masyarakat masih belum seimbang dalam memandang relasi perempuan dan laki-laki. Laki-laki masih dianggap sebagai pribadi yang agung dan mewakili kebaikan dan kesuksesan (misal dalam a man of high principles, a man of mark), sedangkan perempuan masih dianggap sebagai pribadi negatif dan 'sah' dijadikan perumpamaan keburukan (misal dalam "One tongue is enough for a woman"). Namun demikian, tersirat dari idiom dan peribahasa tersebut, penghormatan terhadap perempuan tetap ada meski masih tidak jauh dari peran domestiknya (ibu, kehamilan dan pernikahan).

\section{Konteks}

Berdasarkan konteks situasional dan sosial budaya Indonesia, peribahasa yang banyak muncul dan digunakan pada masa lalu, menyiratkan kedudukan perempuan di ranah domestik (seks, reproduksi dan tugas rumah tangga). Latar munculnya peribahasa berbahasa Indonesia dapat dilihat dari bahasa (Melayu) yang terdapat dalam peribahasa, misalnya Bagai anak dara sudah berlaki, Bakgadis jolong bersubung, Berinduk semang kepada janda bagai berdokoh tali anjing. Meskipun dalam idiom Bahasa Indonesia juga sudah banyak muncul istilah-istilah mutakhir, tetapi juga masih ada ketidakseimbangan, misalnya pada frase kontes kecantikan, peragaan busana, dan lain-lain. Pada idiom kontes kecantikan dan peragaan busana tersirat makna perempuan sebagai objek fisik yang dinikmati oleh lakilaki, bukan dilihat dari keunggulan budi pekerti atau kecerdasannya.

Istilah-istilah dalam idiom dan peribahasa berbahasa Inggris pun tidak jauh berbeda, meskipun dengan nuansa yang tidak begitu kelihatan. Bahasa Inggris masih menampilkan laki-laki sebagai wakil atau tolok ukur kesuksesan dan perempuan sebagai pihak yang tidak lebih unggul dari laki-laki (the weaker sex, an old woman/ cerewet) dengan perannya sebagai ibu (Failure is the mother of success, Prudence is the mother of wisdom).

\section{Historis}

Sejarah panjang di dalam penjajahan dan 'budaya timur' sering dijadikan legitimasi bahwa perempuan Indonesia yang akan maju harus memperhatikan banyak rambu. Sehingga apapun yang menyangkut peran perempuan harus melalui tahapan evaluasi panjang. Istilah-istilah yang muncul di dalam idiom dan peribahasa Indonesia adalah sisa sejarah yang sering menyoalkan relasi perempuan dan laki-laki yang tak ada habisnya. Perjalanan perkembangan bahasa yang menyangkut wacana gender akan berbanding lurus dengan perdebatan tentang relasi gender. Jika perdebatan itu seru, akan semakin bermunculanlah istilah-istilah baru tentang relasi itu. Akan tetapi, anehnya peribahasa lama dengan pola relasi lama, masih ada dan dipelihara.

Meskipun Bahasa Inggris termasuk bahasa modern, masih banyak pula istilah-istilah yang masih mengungkapkan ketidakseimbangan hubungan perempuan dan laki-laki. Namun demikian, banyak lembaga yang telah mengusulkan istilah-istilah yang netral gender, misalnya chairman diganti chairperson atau postman diganti post officer.

\section{Kekuasaan}

Kebanyakan penguasa akan berusaha melanggengkan kekuasaannya melalui berbagai media, tak terkecuali bahasa. Jika 
bahasa dapat membantu melanggengkan kenyamanan berkuasa, maka istilah-istilah yang dipakai tidak jauh dari kenyamanan itu. Perlakuan yang tidak seimbang dalam bahasa diasumsikan sebagai buah dari ketidakseimbangan perlakuan terhadap perempuan atau laki-laki selama ini.

Pengguna bahasa yang merasa tidak terganggu dengan istilah-istilah yang tidak responsif gender juga akan merasakan nyaman-nyaman saja menggunakannya dalam komunikasi sehari-hari, bahkan cenderung mengabadikannya. Contoh yang sangat jelas dilihat terdapat pada kata/morfem man yang dianggap mewakili orang/manusia pada umumnya atau menyatakan keunggulan atau keberhasilan, sementara kata woman atau kata yang mengacu perempuan mengandung makna negatif, lemah atau urusan domestik. Hal ini menunjukkan kekuasaan laki-laki lebih besar daripada perempuan.

\section{Ideologi}

Melalui bahasa dalam bentuk idiom atau peribahasa, ideologi gender sangat mungkin tertanam kuat dan abadi. Dengan kekuatan kata-kata, ideologi dapat diterima dan merasuk ke dalam pikiran dan hati pengguna bahasa (penutur dan lawan tutur). Ideologi yang menguntungkan pihak-pihak tertentu (penguasa, pihakpihak yang berkepentingan) akan cenderung dilegitimasikan melalui berbagai media. Idiom dan peribahasa yang memuat ide gender dapat saja diabadikan lewat media tulis (koran, kamus, buku, dll) maupun elektronik (internet, sinetron, film, dll).

\section{Representasi}

Konsep tentang relasi gender dapat sangatjelasdilihatdandipahamidalambahasa yang digunakan di suatu daerah tertentu. Konsep gender dapat terepresentasikan di dalam idiom dan peribahasa Indonesia dan Inggris melalui kata-katanya yang mengacu kepada jenis kelamin tertentu atau keduanya. Representasi gender di dalam idiom dan peribahasa itulah dapat diketahui bahwa: a. Laki-laki dianggap sebagai wakil banyak urusan (terutama urusan kesuksesan dan kebaikan);

b. Laki-laki sebagai pihak yang aktif dalam pernikahan dan seksualitas

c. Perempuan lebih banyak berperan di ranah domestik

d. Perempuan dijadikan perumpamaan hal-hal yang negatif (cerewet, pemalas, penggoda, dll);

e. Adanya hubungan yang tidak seimbang antara perempuan dan laki-laki.

Dengan demikian, berdasarkan analisis bentuk satuan lingual dan kajian makna dan acuan serta analisis wacana kritis, maka nampaklah representasi wacana gender yang ada di dalam idiom dan peribahasa Indonesia dan Inggris yang masih belum seimbang dalam memperlakukan kedua jenis kelamin, perempuan, dan laki-laki.

\section{SIMPULAN}

Berdasarkan analisis secara intralinguistik, idiom dan peribahasa Indonesia dan Inggris yang mengandung wacana gender berbentuk Nomina, Frase nomina, Frase verba, Frase adjektiva, Frase preposisi, Anak kalimat, Kalimat Tunggal, Kalimat Tunggal/Sederhana (subjek dihilangkan/Elliptical sentence), Kalimat Majemuk Setara, Kalimat Majemuk Bertingkat, dan Kalimat Majemuk Campuran.

Dari analisis makna dan acuan, diketahui adanya makna beragam: kelemahan dan kelebihan seseorang, kesuksesan, pernikahan, seksualitas, hal-hal negatif, dan kebijaksanaan. Dilihat dari pelakunya, idiom dan ungkapan tersebut mengacu kepada jenis kelamin laki-laki, perempuan dan laki-laki dan/atau perempuan. Berdasarkan analisis wacana kritis, terdapat aspek/karakteristik tindakan, historis, konteks, kekuasaan, ideologi dan representasi sehingga diketahui: (a) Laki-laki dianggap sebagai wakil banyak urusan (terutama urusan kesuksesan dan kebaikan); (b) Laki-laki sebagai pihak yang aktif dalam pernikahan dan seksualitas; (c) Perempuan lebih banyak berperan di ranah domestik; (d) Perempuan dijadikan perumpamaan hal-hal yang negatif; dan (e) 
Adanya hubungan yang tidak seimbang antara perempuan dan laki-laki.

\section{DAFTAR PUSTAKA}

Budiwati, Tri Rina, Bias Gender dalam Bahasa Indonesia, A Thesis, Graduate School of Gadjah Mada University, 2003, Unpublished.

Crystal, David, The Cambridge Encyclopedia of Language, Cambridge: Cambridge University Press, 1987.

Echols, John M and Hassan Shadily, Kamus Inggris-Indonesia, An EnglishIndonesian Dictionary, Jakarta: Penerbit PT Gramedia, 1975.

Elliot, J. and A.J. Wooton, “Some Ritual Idioms of Gender in British Television Advertising" in The Sociology Review, 1997. http://www3.interscience. wiley.com/journal/119146665/ abstract?CRETRY $=1 \& S R E T R Y=0$ Accessed on April 27, 2009).

Eriyanto, Analisis Wacana: Pengantar Analisis Teks Media, Yogyakarta: LKIS, 2001.

Fairclough, Norman, Language and Power, Harlow: Longman, Ltd., 1989.

Graddol, David and Joan Swann, Gender Voices, Telaah Kritis Relasi BahasaJender (translation), Pasuruan: Penerbit Pedati, 2003.

Hornby, A.S., et.al, Oxford Advanced Learner's Dictionary of Current English, Oxford: Oxford University Press, 1974.

Kamus Besar Bahasa Indonesia Online.

Kridalaksana, Harimurti, Kamus Linguistik, Jakarta: Penerbit PT Gramedia, 1982.

Miller, Casey dan Kate Swift, "One Small Step for Genkind" in Exploring Language, Goshgarian, Gary (ed.), Fourth Edition, Boston: Little, Brown and Company, 1986.

Mills, Sara, Discourse, New York: Routledge, 1997.

Feminist Stylistics, London: Routledge, 1995.
Moleong, Lexy J, Metodologi Penelitian Kualitatif, Bandung: Penerbit PT Remaja Rosdakarya, 1998.

Nilsen, Alleen Pace, "Sexism in English: A Feminist View" in Language Awareness, Second Edition, Paul Eschholz, et.al, (ed.), New York: St. Martin's Press, 1978.

Podo, Hadi dan Joseph J Sullivan, Pandai Berbahasa Inggris Kamus Ungkapan Indonesia - Inggris, Jakarta: Penerbit PT Gramedia Pustaka Utama, 2000.

Poedjosoedarmo, Soepomo, Penentuan Metode Penelitian, Tidak diterbitkan.

Prasetyono, Dwi Sunar, Kamus Idiom Millenia, 100.000 Ungkapan Bahasa Inggris, Yogyakarta: Pustaka Pelajar, 2003.

Reid, Scott $\mathrm{A}$ and Sik Hung $\mathrm{Ng}$, "Language, Power, and Intergroup Relations" in Journal of Social Issues, Spring, 1999. Accessed 19 November 2008, 2.39 p.m. http:/ / findarticles.com/p/ articles/mi_m0341/is_1_55/ ai_54831713

Subijanto, Rianne Kartikasari, “Representing Bali and Balinese: A Critical Discourse Analysis Approach to Bali's Hotel Brochures" in The Proceedings of the $9^{\text {th }}$ in Southeast Asia Conference, December 13-15 2004, Yogyakarta: Sanata Dharma University, 2004.

Subroto, D. Edi, Pengantar Metoda Penelitian Struktural, Surakarta: Sebelas Maret University Press, 1991.

Sudaryanto, Metode dan Aneka Teknik Analisis Bahasa, Yogyakarta: Duta Wacana University Press, 1993.

Sutopo, Heribertus, Pengantar Penelitian Kualitatif (Dasar-dasar Teoritis dan Praktis), Surakarta: Pusat Penelitian Universitas Sebelas Maret, 1988.

Webster's New World College Dictionary, Third Edition, New York: Macmillan, 1996. 